\title{
Human Sex Differentiation: From Transcription Factors to Gender
}

\author{
Claude J. Migeon Amy B. Wisniewski \\ Johns Hopkins School of Medicine, Department of Pediatrics, Division of Pediatric Endocrinology, \\ Johns Hopkins University, Baltimore, Md., USA
}

\section{Key Words}

Sex · Gender - Sex differentiation - Transcription factors • Hormone receptors

\begin{abstract}
Over the past decade, knowledge of the genetic control of human sex differentiation has greately expanded our understanding of the developmental processes needed to form a male or female. The purpose of this review is to discuss how transcription factors are relevant to such processes. Additionally, an attempt is made to relate current knowledge of these factors with gender development of subjects with intersex conditions. Finally, we discuss how information about the genetic control of sex differentiation may contribute to decisions about medical treatment of individuals with conditions of abnormal sex differentiation.
\end{abstract}

Copyright $(2000$ S. Karger AG, Basel

\section{Introduction}

In our previous review of human sexual differentiation [1] we succinctly presented the major physiological steps involved. The first step, the genetic sex of the fertilized

\section{KARGER \\ Fax + 41613061234 \\ E-Mail karger@karger.ch} www. karger.com (c) 2000 S. Karger AG, Basel

Accessible online at: www. karger.com/journals/hre egg, depends upon the chromosomal complement $(23, \mathrm{X}$ or $23, \mathrm{Y}$ ) of the fertilizing sperm. This is followed by the formation of undifferentiated structures that are common to both sexes: two sets of undifferentiated sex ducts (müllerian and wolffian duct systems), the gonadal ridge and the external genitalia. In a third step, the testis determining factor (TDF) is responsible for testis determination. In the absence of TDF, other factors permit ovarian formation.

The final classical steps in sexual differentiation are based on testicular functions: the Sertoli cells of the testes secrete müllerian inhibiting substance (MIS) that suppresses the development of female ducts. Simultaneously, the Leydig cells of the testes secrete large amounts of testosterone that promote the growth of male ducts and masculinizes the external genitalia. In contrast, the ovaries do not secrete significant amounts of testosterone, resulting in the disappearance of male ducts and lack of masculinization of the external genitalia that remains female. Also, the ovaries to not produce MIS early in fetal development, which leads to development of female ducts. The physiologic understanding of this fourth step in sexual differentiation is a result of the contributions of Alfred Jost, Nathalie Josso and colleagues.

In the past 10 years, it has been realized that the phenotypic formation of males and females is more complex

Claude J. Migeon, MD, Professor of Pediatrics

Johns Hopkins School of Medicine

600 N, Wolfe Street/Park 211

Baltimore, MD 21287 (USA)

Tel. +1 4109556463 , Fax +1 4109559773 
than previously thought. This realization is due to progress in our understanding of the mechanisms involved in controlling gene expression. Indeed, it is now clear that the expression of many genes is tightly controlled by products termed transcription factors. Hence, in what follows, we will summarize our current knowledge of these factors as they relate to human sexual differentiation.

\section{The Fertilized Egg}

The first step in sex differentiation takes place at the time of fertilization of the ovum by one sperm. Several sperm attempt to reach the ovum, a few penetrate the zona pellucidum surrounding the egg, but only one will attach itself and fuse its acrosome (male pronucleus) to the membrane of the egg. At this point, no other sperm can fuse with the egg.

Later, the acrosome is included into the cytosol of the egg, while the nucleus of the egg divides and eliminates the second polar body. The female pronucleus joins with that of the male, resulting in a diploid cell: the fertilized egg.

At this point, the zygote includes 23 maternal chromosomes and 23 paternal chromosomes as well as maternal mitochondrial DNA. This corresponds to approximately 3.5 billion base pairs of DNA that are organized into $100,000-150,000$ genes. Each of these genes is transcribed into a specific protein, and these proteins will organize themselves into tissues, the tissues into organ systems and these organs will form a woman or a man.

It is of interest to pause and reflect on the fact that within this single fertilized egg, all of the necessary genetic information is present for development of a multicellular organism with specialized functional systems: the human body. This is the result of a specific pattern of activation of the various genes of the zygote. However, all genes are not functional at the same time or with the same degree of expression throughout development. The so-called 'housekeeping' genes are expressed all of the time, although not always at the same level. These genes are required for the overall maintenance and energy expenditure of cells. Without them, a cell would not be viable. Yet, it is evident that the energy requirements of a cell will vary throughout its life cycle. As a result, the expression of housekeeping genes is somewhat modulated to fit cellular needs.

In contrast, genes with highly specialized functions have expression patterns that are tightly modulated and controlled by specific factors, the transcription factors.
Control of gene expression by transcription factors is exerted in a temporal fashion that is unique to these genes. Control is also exerted in a quantitative fashion, as related to certain cellular needs.

\section{Transcription Factors - Definition and Classifications}

Gene expression is regulated at several levels. It is controlled first at the transcription level, followed by posttranscriptional processing resulting in the formation of mRNA. The next step is regulation of mRNA translation with post-translational processing.

Transcription factors are trans-acting elements that bind selectively to appropriate cis-acting DNA sequences of the promoter of a gene. This interaction results in regulation (up-regulation or down-regulation) of the rate of gene transcription by the 'transcription initiation complex'. As already stated, transcription factors can act as activators or repressors of gene transcription. If they work in concert with other modulating elements, transcription factors can be co-activators or co-repressors. Some transcription factors act by changing the configuration of DNA and are named architectural factors or high mobility group (HMG) proteins.

Transcription factors can be classified on the basis by which they bind to DNA. DNA-binding domains include homeodomains, zinc finger domains, basic leucine zipper domains and basic helix-loop-helix domains [2].

\section{Detection and Study of Transcription Factors Involved in Sex Differentiation}

It is often difficult to establish beyond doubt the role of a protein that includes a DNA-binding domain. Detection of genes involved in sex differentiation is accomplished with chromosomal studies of patients presenting certain phenotypes. For example, the locus of SRY was identified by studying patients with $\mathrm{XX}$ sex reversal (a variant of Klinefelter syndrome) and female infants with a 46,XY complement (complete gonadal dysgenesis or Swyer syndrome).

An additional approach is the determination of the timing of gene expression in sexual structures; the appearance of a factor at a specific time in development of an organ suggests that the factor plays a definite role in the evolution of that organ. In 'knock-out' studies the resulting effects of suppression of a gene suggests the role of that 
gene. In vitro studies with expression vectors help to identify the effects of one gene product on the expression of another gene. The combination of these techniques have provided important information about the mechanisms involved in human sex differentiation.

\section{Transcription Factors Involved in Sex Differentiation}

Although our knowledge remains limited, a number of transcription factors have been shown to play a role in human sex differentiation. These include homeodomain proteins like LIM1, zinc finger domain proteins like SF-1, WT-1, DAX-1, the androgen receptor (AR) and HMG proteins like SRY and SOX-9. Each of these factors has a unique and specific action in the overall process of sex differentiation; however, the absence of any one can result in a similar phenotype of gonadal dysgenesis.

\section{Homeodomain Proteins}

The homeobox is a well-conserved 180 base pair region of DNA that encodes for a 60 -amino-acid motif. This motif has a structure that includes $3 \alpha$-helices with a terminal arm. Homeodomain proteins contact DNA in a major groove.

\section{LIM1 Gene (Chromosome 11p12-13)}

LIM1 is an example of a homeobox gene important to sex differentiation. The LIM1 protein contains not only a homeodomain, but it also has 2 zinc fingers comprised of 4 cysteines each. LIM1 has multiple roles in activating and inhibiting many genes necessary to the general organization of various organ systems including those involved in sex differentiation. In Lim 1 knock-out mice, the developmental result in an organism with no head, kidneys or gonads [3]. Homozygous deletions of Lim1 in mice result in absence of kidneys, gonads and cranium. This transcription factor is thought to organize other proteins in the mesoderm, but the characterization of these proteins is not known at this time due in part to the lethality of Lim1 mutations. The human LIM1 gene has been identified [4]; however, mutations have yet to be reported.

\section{Nuclear Receptors}

A second group of transcription factors important to sex differentiation is the nuclear receptor superfamily, consisting of a large number of proteins with a common zinc finger element. Zinc fingers are formed by a zinc molecule attached to 4 molecules of cysteine (or 2 cysteines and 2 histidines). Typically, nuclear receptors contain 3 domains: a DNA-binding domain represented by zinc fingers, a ligand-binding domain and a transactivator or modulator domain.

\section{SF-1 Gene (Chromosome 9q33)}

A nuclear receptor transcription factor associated with sex differentiation is SF-1. The SF-1 protein contains the 3 typical domains mentioned above. However, because the identity of the ligand is unknown at this time, SF-1 is considered to be a member of the orphan nuclear receptor family.

The first known role of SF-1 was that its protein is a regulator of cytochrome $\mathrm{P}_{450}$ steroid hydroxylases important to adrenal and gonadal steroid synthesis. SF-1 also activates the ACTH receptor. A third role for SF-1 is activation of the expression of MIS [5]. The MIS and MIS receptor II genes possess a specific sequence in their promoter regions (AGGTCA) to which SF-1 can bind and exert activating effects [6]. SF-1 can also synergize with WT-1 to regulate MIS activity [7].

In studies of Sf-1 knock-out mice, gonadal development stops at the early stage of the urogenital ridge. Development of adrenals is also blocked in these animals [5]. Furthermore, gonadotrope cell function of the anterior pituitary is impaired in these animals, as is the ventromedial hypothalamic region ( $\mathrm{VMH})$ that is an important neural component for rodent lordosis and feeding behavior [8].

Regardless of karyotype, both 46,XX and 46,XY Sf-1 knock-out mice fail to develop gonads or adrenal glands, and exhibit female external genitalia and female duct development along with male duct regression. A single case of a human SF-1 mutation has been described. This $46, \mathrm{XY}$ subject presented with female external genitalia, müllerian duct development and adrenal failure [9].

In summary, SF-1 plays a major role in the early development of the undifferentiated gonads, the anlage of the adrenal glands, and areas in the central nervous system necessary for secretion of gonadotropins and reproductive behaviors in nonhuman animals. SF-1 regulates MIS activity and it is necessary for steroid synthesis. 


\section{WT-1 Gene (Chromosome 11p13)}

A second nuclear receptor to be considered is the Wilms' tumor gene (WT-1). This gene encodes for a transcription factor containing 2 zinc fingers [10, 11]. WT-1 binds to the DNA sequence CGCCCCCGC and is believed to act both as a transcriptional activator and repressor [12].

Mutations of WT-1 result in Wilms' tumors [13], which are embryonic tumors of the kidney. In some cases, the 'WAGR phenomenon' presents itself in subjects with autosomal dominant WT-1 mutations. This phenomenon includes the Wilms' tumor, Aniridia, Gonadal dysgenesis, and mental Retardation.

A second syndrome related to heterozygous WT-1 mutations is Denys-Drash syndrome [14]. This syndrome is characterized by kidney problems (of the Wilms' tumor type) and gonadal dysgenesis. Reduced WT-1 binding to DNA has been identified in patients with Denys-Drash syndrome [15]. Ambiguity of external genitalia occurs only in 46,XY subjects, while 46 ,XX subjects have normal female external genitalia as expected from the work of Jost.

A third syndrome known to be associated with WT-1 mutations is Frasier syndrome. This includes focal glomerular sclerosis of the kidneys in addition to gonadal dysgenesis. In subjects with Frasier syndrome, an abnormal splicing is thought to occur at intron 9 of the WT-1 gene [16].

Experiments with knock-out mice indicate that the absence of Wt-1 is associated with normal early development of the urogenital ridge, followed shortly thereafter by a complete block in gonadal development [17]. In other words, WT-1 appears to be important for maturation of the urogenital ridge prior to differentiation of the bipotential gonad.

\section{HMG Proteins}

HMG protein transcription factors are also known as DNA sequence-specific binding factors. These factors bind to specific sequences of DNA, such as AACAAT and AACAAAG. Because several sequence-specific binding factors can bind to the same base pair series, HMG proteins acquire individual specificity indirectly via other cofactors.

HMG proteins bind to the minor groove in DNA and result in a $60-85^{\circ}$ bend at which point the DNA can unwind and widen $[18,19]$. This binding to DNA may act to stabilize the binding of other proteins, or perhaps pro- vide a binding site for specific activators. HMG proteins involved in sex differentiation include products of the SRY and SOX-9 genes. Both of these proteins are thought to be necessary for the differentiation of the early, bipotential gonad into a testis.

\section{SRY Gene (Chromosome Yp 11.3)}

The SRY gene produces an HMG protein that can bend DNA [20], and is therefore referred to as an 'architectural factor'. The SRY gene encodes a 204-amino-acid protein. The HMG domain of this protein is comprised of a highly conserved 79-amino-acid region [21].

It has been suggested that the specific role of SRY in testis differentiation is to suppress genes involved in female differentiation [22], or that it activates genes necessary for male differentiation such as the MIS gene $[19,23]$. Knowledge pertaining to precise mechanisms through which SRY triggers testis differentiation from an undifferentiated gonad has not been established.

As previously noted, the mapping of deletions of the $\mathrm{Y}$ chromosome in 46,XY females and additions to the $X$ chromosome in $46, X X$ males permitted the identification of the sex-determining region Y (SRY) gene. The importance of Sry for testis determination was confirmed by injecting the gene in XX fertilized eggs of mice. The result was offspring with testes and male genitalia [24].

What is known about SRY in humans is that mutations of this gene can result in cases of complete gonadal dysgenesis among 46,XY individuals [19]. In complete gonadal dysgenesis, development of the undifferentiated gonad stops at an early stage. Sertoli cells do not develop, no MIS is secreted and female ducts differentiate. Leydig cells are absent resulting in a lack of production of testicular androgens. In such conditions female genitalia develop and wolffian ducts regress. In other words, individuals with complete gonadal dysgenesis possess a 46,XY karyotype, have female ducts and possess female external genitalia.

In most cases of complete gonadal dysgenesis with SRY mutations, the majority of mutations occur within the HMG box. However, only $10-15 \%$ of cases demonstrate an SRY mutation. While SRY is necessary for testis differentiation from a bipotential gonad, factors other than SRY are also required [25].

SOX-9 Gene (Chromosome 17q-24.3-25.1)

A second HMG protein important to the process of testis differentiation is SOX-9. Like SRY, SOX-9 binds to DNA at the base pair sequences AACAAT or AACAAAG [26]. Specificity of SOX-9 is acquired through conjugation with cofactors. 
SOX-9 also binds to the DNA sequences ATGAAT and CACAAT [27]. These sequences are involved with chondrocyte-specific enhancers and type II collagen formation. This explains why abnormalities of SOX-9 result in abnormalities of both bone formation and sex differentiation.

SOX-9 mutations in humans can result in a syndrome known as campomelic dysplasia (CD), which is an autosomal dominant trait $[28,29]$. CD is characterized by a disorder of chondrocytes that results in multiple bone dysplasia. In $46, \mathrm{XY}$ subjects affected by $\mathrm{CD}$, approximately $75 \%$ exhibit abnormalities in sex differentiation ranging from a normal-appearing female phenotype to an ambiguous one [30]. Phenotypic variation regarding abnormal sex differentiation of subjects with SOX-9 mutations probably relates to the penatrance of this mutation. It is of interest that SOX-9 mutations resulting in gonadal abnormalities are associated with abnormalities of chondrocytes, whereas mutations resulting in chondrocyte abnormalities are not always associated with gonadal abnormalities.

A possible mechanism of action of SOX-9 is that this gene is regulated by SRY for the differentiation and longterm maintenance of Sertoli cells. An additional, and not mutually exclusive, role of SOX-9 may be suppression of ovarian differentiation from an undifferentiated gonad [22]. Finally, SOX-9 has been shown to interact with the nuclear receptor SF-1 in regulating the MIS gene promoter [31].

\section{Two Additional Nuclear Receptors}

\section{DAX-1 Gene (Chromosome Xp21)}

DAX-1 is an atypical orphan nuclear receptor in that the structure of this receptor does not include zinc fingers in the DNA-binding domain. Instead, DAX-1 binds to DNA via hairpin structures [32].

Results of DAX-1 mutations are similar to those described for SF-1. Specifically, there is adrenal cortex hypoplasia, hypogonadotropic hypogonadism and disruption to the ventromedial region of the hypothalamus [33, 34]. However, in contrast to SF-1, DAX-1 mutations do not result in a total arrest of testicular or adrenal development [35].

$46, \mathrm{XY}$ subjects with a duplication of the DAX-1 gene exhibit partial gonadal dysgenesis, and 46,XY subjects with DAX-1 deletions develop testes [36]. Additionally, a $46, \mathrm{XX}$ subject with a homozygous DAX-1 mutation exhibited ovarian development [37]. Therefore, DAX-1 is considered to be a dosage sensitive 'anti-testis' factor as opposed to a gene necessary for ovary differentiation [35, 38].

DAX-1 protein appears to be an important protein transcription inhibitor. DAX-1 inhibits SF-1 transactivation [39] and also antagonizes the synergy that exists between SF-1 and WT-1 [7]. DAX-1 inhibits activity of the enzymes StAR [40], CYP11A and 3 $\beta$-hydroxysteroid dehydrogenase [41]. These observations suggest that DAX-1 acts as an SRY antagonist [35].

\section{AR Gene (Chromosome Xq11-12)}

The human AR gene is a single-copy gene comprised of 8 exons that encode for a protein consisting of 919 amino acids $[42,43]$. The ligand-binding domain of the AR protein binds to dihydrotestosterone (DHT) with very high affinity and to testosterone with lower affinity. The ARDHT complex forms a homodimer that binds to a specific DNA acceptor site to promote gene transcription [44]. The product of this activated gene transcription represents the androgen effect on the target cells.

The phenotype of 46,XY subjects and total absence of AR expression is complete androgen insensitivity syndrome (CAIS). Individuals with CAIS exhibit normal female external genitalia with a short vagina that ends blindly. Two normally formed testes are present and are undescended or found in the inguinal area. Women with CAIS possess no müllerian ducts, and wolffian duct development is usually absent or limited. At puberty, girls with CAIS develop breasts, but exhibit sparse amounts of pubic or axillary hair [45].

Multiple AR gene mutations have been identified, with the majority occurring in exons 2 through 8 , although a few have been identified in exon 1 . These mutations [see website www.mcgil.ca/androgendb] result in either a complete or partial form of AIS.

\section{A Scheme for the Role of Presently Known Transcription Factors Involved in Sex Differentiation}

Although our knowledge remains limited, an attempt can be made to integrate the roles played by transcription factors involved in sex differentiation (fig. 1). It appears that LIM1 is involved in the formation of the urogenital ridge early in embryonic development [3]. Next, the effects of SF-1 and WT-1 are necessary to develop the ridge into a bipotential gonad $[5,9,17]$. Thereafter the SRY protein, along with SF-1, WT-1 and SOX-9 is 


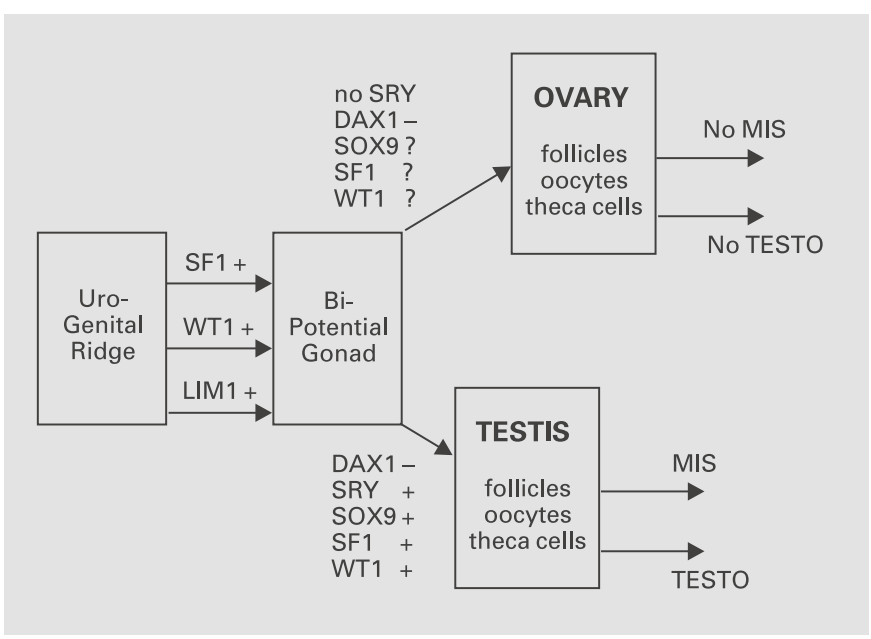

Fig. 1. A scheme for the role of presently known transcription factors involved in human sex differentiation. LIM1 most likely plays a role in formation of the urogenital ridge. SF-1 and WT-1 are necessary for the development of the bipotential gonad. SRY is needed to differentiate the gonad into a testis, with the help of SOX-9, SF-1 and WT-1. In the absence of SRY-DAX-1 appears to counteract the effects of SF-1, SOX-9 and WT-1, leading to development of an ovary.

needed to differentiate the gonad into a testis, including Sertoli cells that produce MIS and Leydig cells that secrete testosterone [24]. This is possible in the presence of a single dose of DAX-1, as duplication of this gene results in ambiguous genitalia in a 46,XY subject [35, 38].

In a 46,XY embryo, the absence of SRY permits full expression of genes that allow for the differentiation of an ovary.

\section{A Theoretical Outline of the Interactions of Transcription Factors}

On the basis of various studies, it is possible to construct a system of the control of expression of the MIS gene. The SRY protein may potentiate the expression of the SF-1 gene [19]. Then, the SF-1 protein, in collaboration with the SOX-9 protein, exerts a strong positive effect on the expression of the MIS gene [31]. WT-1 also appears to contribute a positive effect on the MIS gene [7]. The combined positive action of SF-1, SOX-9 and WT-1 oppose the negative effect of DAX-1. The result is early expression of the MIS gene with consequent suppression of müllerian duct development (fig. 2).

In contrast, the absence of the SRY protein results in a lack (or decrease) of a positive effect of SF-1 on MIS gene

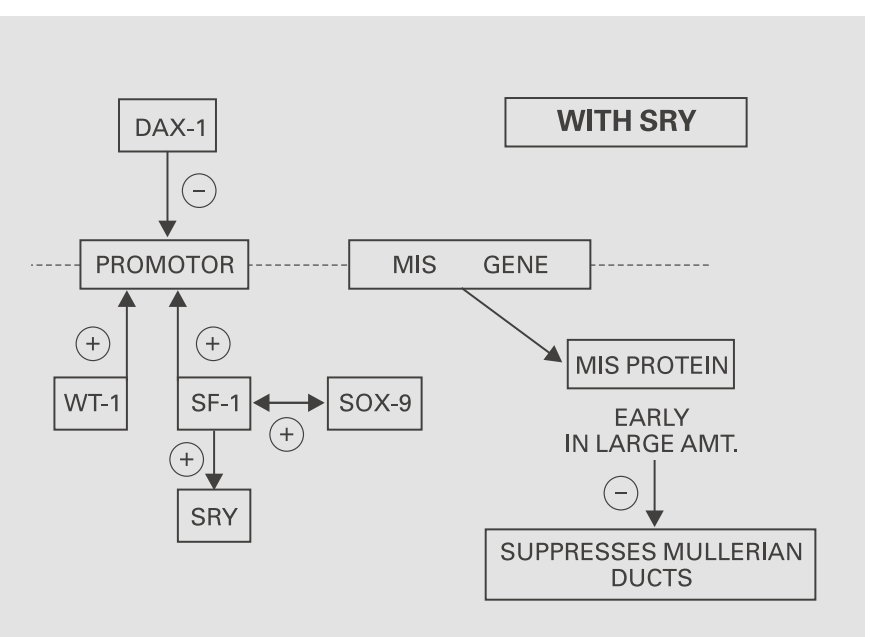

Fig. 2. Expression of the MIS gene is modulated by many transcription factors. The WT-1 protein in collaboration with SOX-9 exert a strong positive effect on the MIS gene promoter. SRY protein also exerts a positive effect on the MIS gene by potentiating the expression of the SF-1 gene. This collection of positive transcription factors overrides the negative effect of DAX-1 on the MIS promoter. The result is early transcription of the MIS gene, leading to suppression of müllerian duct development in a 46,XY fetus.

activity [19, 23]. Under such conditions the negative action of DAX-1 is prominent, and the MIS protein appears later and/or in smaller amounts. This leads to development of müllerian structures (fig. 3).

Clearly, the above speculations may not be entirely accurate. This scheme, however, illustrates the fine monitoring exerted by transcription factors on the expression of genes, such as the MIS gene, important to sex differentiation.

It is also important to emphasize that several additional transcription factors are likely involved in human sex differentiation. For example, there is a series of SOX genes (SRY-related homeobox genes) that could play a role in sex differentiation such as SOX-3 [25]. Additionally, a haplo-deletion of distal 9p chromosomal material (genes DMRT1 and DMRT2) results in 46,XY subjects with variable degrees of gonadal dysgenesis [46-48].

\section{Transcription Factors and Human Behavior}

Sex differences in human behaviors are well documented, and to a lesser extent sex differences in human CNS structures have been identified [49]. However, it is unclear how these dimorphic structures relate to behaviors such as gender identity/role (GI/R) and sexual orien- 


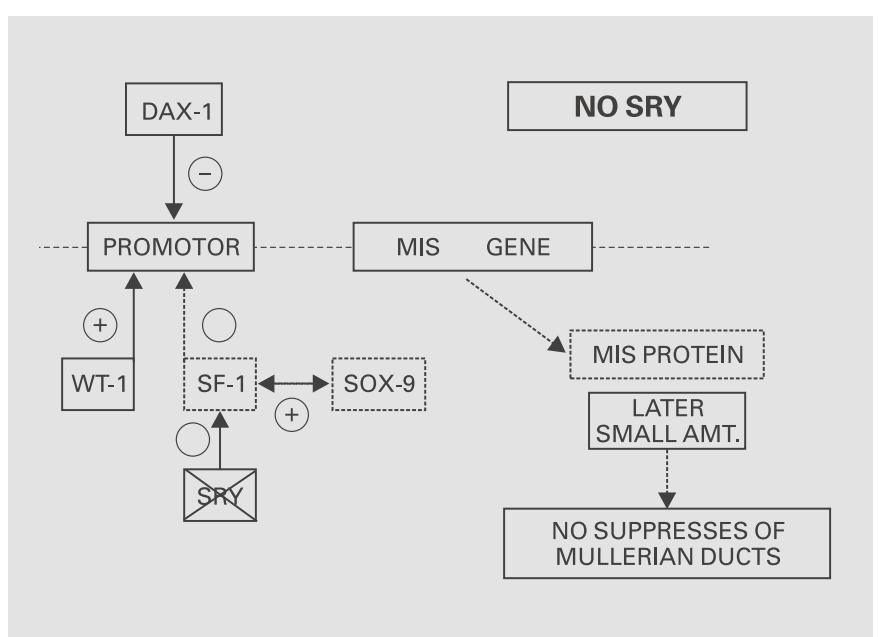

Fig. 3. In the absence of SRY, the positive effect of SF-1 on MIS gene expression is greatly decreased. Under such conditions, the negative effect of DAX-1 predominates and results in absent (and/or late) expression of the MIS gene. This permits development of müllerian ducts in a 46,XX fetus.

tation. Even if direct associations can be established between sexually-dimorphic brain structures and behaviors, it remains difficult to identify a causal relationship between the two.

Transcription factors are essential to the physiologic processes involved in phenotypic sex differentiation, however it is unclear if these factors are important to gender development. SF-1 and DAX-1 are expressed in the hypothalamus, and steroid hormone receptors (AR, ER $\alpha$ and ER $\beta$ ) are located throughout the CNS. Therefore, these proteins would be the most likely candidates for influencing gender.

In the case of steroid hormone receptors that are required to potentiate the activity of male and female hormones, their influence on brain function is probably entirely related to the action of sex steroids. This hypothesis is supported by patients with complete androgen insensitivity syndrome and complete gonadal dysgenesis, where members of both diagnostic groups develop female GI/R [50].

If male gender development is related to the exposure of the brain to androgens during fetal life - a hypothesis that has yet to be proven in humans - then there is no question about raising 46,XY individuals with a complete absence of androgen secretion or androgen expression as females. This includes subjects with complete gonadal dysgenesis related to abnormalities of the known transcription factors (LIM1, SF-1, WT-1, SRY and SOX-9) as well as CAIS (AR). Also included are subjects with conditions of complete deficiency of enzymes involved in the biosynthesis of testosterone from cholesterol.

Mutations resulting in partial deficiency of these gene products are expected to result in ambiguous external genitalia, and possibly partial brain masculinization as well. In such cases, the dilemma is to decide what is preferable: a masculinized female or an undermasculinized male. It is clear that there is no fully satisfactory answer for these individuals. It would be logical to suggest that minimally masculinized individuals are more easily raised as females, whereas markedly masculinized individuals might be happier if raised as males. However, this leaves a large group of patients with truly ambiguous genitalia. Such a situation may support the view that the final decision for sex of rearing should be left to the patient once that individual is prepared to make such a choice. In such cases, the civil rights of an individual to choose his/her sex would appear justified [ISNA, www.isna.org].

Unfortunately, delay in assigning the sex of rearing (gender) of a child presents another question: the parental viewpoint that it is optimal to assign a sex of rearing as early as possible. Parents strongly feel that it is their responsibility to establish a sex of rearing for their child early in that child's life. As a corollary, parents also believe that appropriate reconstructive surgery to masculinize or feminize the external genitalia should be obtained as soon after birth as possible. This feeling is also shared by many adults born with ambiguous genitalia.

Perhaps a solution is available. With some unusual, although notable, exceptions, most of our patients accept their sex of rearing (male or female). Most recognize that their genital abnormality was, and continues to be, a major problem coupled with the reality that surgical correction is never perfect. Despite this, the majority have achieved a satisfactory quality of life in accordance with their sex of rearing.

\section{Acknowledgements}

This work was supported by a grant from The Genentech Foundation for Growth and Development 98-33C to C.J.M., an NIH NRSA grant F32HD08544 to A.B.W. and an NIH, NCRR, GCRC grant RR00052. This work was originally presented as the 1999 Robert L. Ney Memorial Lecture at Johns Hopkins University by C.J.M. 


\section{References}

1 Migeon CJ, Wisniewski AB: Sexual differentiation: From genes to gender. Horm Res 1998;50: 245-251.

2 Semenza GL: Transcription factors and human disease. Oxford Monographs on Medical Genetics, No 37. New York, Oxford University Press, 1998.

3 Shawlot W, Behringer RR: Requirement for Lim 1 in head-organizer function. Nature 1995; 374:425-430.

4 Dong WF, Heng HH, Lowsky R, Xu Y, DeCoteau JF, Shi XM, et al: Cloning, expression, and chromosomal localization to $11 \mathrm{p} 12-13$ of a human LIM/HOMEOBOX gene, hLim-1. DNA Cell Biol 1997; 16:671-678.

5 Parker KL, Schimmer BP: Steroidogenic factor 1: A key determinant of endocrine development and function. Endocr Rev 1997;18:361377.

6 Barbara PS, Moniot B, Poulat F, Boizet B, Berta $\mathrm{P}$ : Steroidogenic factor-1 regulates transcription of the human anti-müllerian hormone receptor. J Biol Chem 1998;273:29654-29660.

7 Nachtigal MW, Hirokawa Y, Enyeart-Van Houten DL, Flanagan JN, Hammer GD, Ingraham HA: Wilms' tumor 1 and DAX-1 modulate the orphan nuclear receptor SF-1 in sexspecific gene expression. Cell 1998;93:445454.

8 Shinoda K, Lei H, Yoshii H, Nomura M, Nagano M, Shiba H, et al: Developmental defects of the ventral medial hypothalamic nucleus and pituitary gonadotroph in the Ftz-F1 disrupted mice. Dev Dynam 1995;204:22-29.

9 Achermann JC, Ito M, Ito M, Hindmarsh PC, Jameson JL: A mutation in the gene encoding steroidogenic factor-1 causes XY sex reversal and adrenal failure in humans. Nat Genet 1999;22:125-126.

10 Call KM, Glaser T, Ito CY, Buckler AJ, Pelletier J, Haber DA, et al: Isolation and characterization of a zinc finger polypeptide gene at the human chromosome 11 Wilms' tumor locus. Cell 1990;60:509-520.

11 Hastie ND: The genetics of Wilms' tumor - A case of disrupted development. Annu Rev Genet 1994;28:523-558.

12 Drummond IA, Madden SL, Rohwer NP, Bell GI, Sukhatme VP, Rauscher F: Repression of the insulin-like growth factor gene by the Wilms' tumor suppressor gene WT1. Science 1992;257:674-678.

13 Francke U, Holmes LB, Atkins L, Riccardi VM: Aniridia-Wilms' tumor association: Evidence for specific deletion of $11 \mathrm{p} 13$. Cytogenet Cell Genet 1979;24:185-192.

14 Little M, Wells C: A clinical overview of WT1 gene mutations. Hum Mutat 1997;9:209-225.

15 Borel F, Barilla KC, Hamilton TB, Iskandar M, Romaniuk PJ: Effects of Denys-Drash syndrome point mutations on the DNA-binding activity of the Wilms' tumor suppressor protein WT1. Biochemistry 1996;35:12070_ 12076 .
16 Barbaux S, Niaudet P, Gubler MC, Grunfeld JP, Jaubert F, Kuttenn F, et al: Donor splicesite mutations in WT1 are responsible for Frasier syndrome. Nat Genet 1997; 17:467-470.

17 Kreidberg JA, Sariola H, Loring JM, Maeda M, Pelletier J, Housman D, Jaenisch R: WT-1 is required for early kidney development. Cell 1993;74:679-691.

18 Giese K, Pagel J, Grosschedl R: Distinct DNAbinding properties of the high mobility group domain of murine and human SRY sex-determining factors. Proc Natl Acad Sci USA 1994; 91:3369-3374.

19 Haqq CM, King CY, Ukiyama E, Falsafi S, Haqq TN, Donahoe PK, Weiss MA: Molecular basis of mammalian sexual determination: Activation of müllerian inhibiting substance gene expression by SRY. Science 1994;266:14941500.

20 Ferrari S, Harley VR, Pontiggia A, Goodfellow PN, Lovell-Badge R, Bianchi ME: SRY, like HMG-1, recognizes sharp angles in DNA. EMBO J 1992;11:4497-4506.

21 Jantzen HM, Admon A, Bell SP, Tjian R: Nucleolar transcription factor hUBF contains a DNA-binding motif with homology to HMG proteins. Nature 1990;344:830-836.

22 Koopman P: Sry and Sox 9: Mammalian testisdetermining genes. Cell Mol Life Sci 1999;55: 839-856.

23 Haqq CM, King CY, Donahoe PK, Weiss MA SRY recognizes conserved DNA sites in sexspecific promoters. Proc Natl Acad Sci USA 1993;90:1097-1101

24 Koopman P, Gubbay J, Vivian N, Goodfellow $\mathrm{P}$, Lovell-Badge R: Male development of chromosomally female mice transgenic for SRY. Nature 1991;351:117-121.

25 Lim HN, Freestone SH, Romero D, Kwok C, Hughes IA, Hawkins JR: Candidate genes in complete and partial XY sex reversal: Mutation analysis of SRY, SRY-related genes and FTZ-F1. Mol Cell Endocrinol 1998;140:5158.

26 Tommerup N, Schempp W, Mienecke P, Pedersen S, Bolund L, Brandt C, et al: Assignment of an autosomal sex reversal locus (SRA1) and compomelic dysplasia (CMPD1) to 17q24.3-q25.1. Nat Genet 1993;4:170-174.

27 Bell DM, Leung KKH, Wheatley SC, Ng LJ, Zhou S, Ling KW, et al: SOX-9 directly regulates the type-II collagen gene. Nat Genet 1997; 16:174-178.

28 Foster JW, Dominguez-Steglich MA, Guioli S, Kwok C, Weller PA, Weissenbach J, et al: Campomelic dysplasia and autosomal sex reversal caused by mutations in an SRY-related gene. Nature 1994;372:525-530.

29 Wagner T, Wirth J, Meyer J, Zabel B, Held M, Zimmer $\mathrm{J}$, et al: Autosomal sex reversal and campomelic dysplasia are caused by mutations in and around the SRY-related gene SOX-9. Cell 1994;79:1111-1120.
30 Kwok C, Weller PA, Guioli S, Foster JW, Mansour S, Zuffardi O, Punnett $\mathrm{HH}$, et al: Mutations in SOX-9, the gene responsible for campomelic dysplasia and autosomal sex reversal. Am J Hum Genet 1995;57:1028-1036.

31 Barbara P, Bonneaud N, Boizet B, Desclozeaux M, Moniot B, Südbeck P, et al: Direct interaction of SRY-related protein SOX-9 and steroidogenic factor 1 regulates transcription of the human anti-müllerian hormone gene. Mol Cell Biol 1998;18:6653-6665.

32 Zazopoulos E, Lalli E, Stocco DM, SassoneCorsi P: DNA binding and transcriptional repression by DAX-1 blocks steroidogenesis. Nature 1997;390:311-315.

33 Guo W, Burris TP, McCabe ER: Expression of DAX-1, the gene responsible for X-linked adrenal hypoplasia congenita and hypogonadotropic hypogonadism, in the hypothalamic-pituitary-adrenal/gonadal axis. Biochem Mol Med 1995;56:8-13.

34 Kletter GB, Gorski JL, Kelch RP: Congenital adrenal hypoplasia and isolated gonadotropin deficiency. Trends Endocrinol Metab 1991;2: 123-128.

35 Goodfellow PN, Camerino G: DAX-1, an 'antitestis' gene. Cell Mol Life Sci 1999;55:857863.

36 Bardoni B, Zanaria E, Guioli S, Floridia G, Worley KC, Tonini G, et al: A dosage-sensitive locus at chromosome $\mathrm{Xp} 21$ is involved in male-to-female sex reversal. Nat Genet 1994;7: 497-501.

37 Merke DP, Tajima T, Baron J, Cutler GB: Hypogonadotropic hypogonadism in a female caused by X-linked recessive mutation in the DAX-1 gene. N Engl J Med 1999;340:12481252.

38 Roberts LM, Shen J, Ingraham HA: New solutions to an ancient riddle: Defining the differences between Adam and Eve. Am J Hum Genet 1999;65:933-942.

39 Lalli E, Bardoni E, Zopopoulos E, Wurtz JM, Strom TM, Moras D, Sassone-Corsi P: A transcriptional silencing domain in DAX-1, whose mutation causes adrenal hypoplasia congenita. Mol Endocrinol 1997;11:1950-1960.

40 Sandhoff TW, Mc Lean MO: Repression of the rat steroidogenic acute regulatory (StAR) protein gene by PGF $2 \alpha$ is modulated by the negative transcription factor DAX-1. Endocrine 1999;10:83-91.

41 Lalli E, Melner MH, Stocco DM, Sassone-Corsi P: DAX-1 blocks steroid production at multiple levels. Endocrinology 1998;139:42374243.

42 Kuiper GGJM, Faber PW, van Rooij HCJ, van der Korput JAGM, Ris-Staplers C, Klassen P, Trapman J, Brinkmann AO: Structural organization of the human androgen receptor gene. Mol Endocrinol 1989;2:R1-R4. 
43 Lubahn DB, Brown TR, Simental JA, Higgs HN, Migeon CJ, Wilson EM, French FS: Sequence of the intron/exon junctions of the coding region of the human androgen receptor gene and identification of a point mutation in a family with complete androgen insensitivity. Proc Natl Acad Sci USA 1989;86:9534-9538.

44 Wong CI, Zhou ZX, Sar M, Wilson EM: Steroid requirement for androgen receptor dimerization and DNA binding. J Biol Chem 1993; 268:19004-19012.
45 Migeon CJ, Brown TR, Fichman KR: Androgen insensitivity syndrome; in Josso N (ed): The Intersex Child. Basel, Karger, 1981, pp 171-202.

46 Huret JL, Leonard C, Forestier B, Rethore MO, LeJeune J: Eleven new cases of del(9p) and features from 80 cases. J Med Genet 1988 ; 25:741-749.

47 Raymond CS, Parker ED, Kettlewell JR, Brown LG, Page DC, Kusz K, et al: A region of human chromosome $9 p$ required for testis development contains two genes related to known sexual regulators. Hum Mol Genet 1990;8: 989-996.
48 Ogata T, Muroya K, Matsuo N, Hata J, Fukushima Y, Suzuki Y: Impaired male sex development in an infant with molecularly defined partial 9p monosomy: Implication for a testis forming gene(s) on 9p. J Med Genet 1997;34: 331-334.

49 Collaer ML, Hines M: Human behavioral sex differences: A role for gonadal hormones during early development? Psychal Bull 1995;118: 55-107.

50 Migeon CJ: Paper presented at LWPES, San Francisco, Calif., 1999. 
Copyright: S. Karger AG, Basel 2000. Reproduced with the permission of S. Karger AG, Basel. Further reproduction or distribution (electronic or otherwise) is prohibited without permission from the copyright holder. 